\title{
AKIBAT HUKUM DARI PERATURAN PERUBAHAN MODAL DASAR PERSEROAN TERBATAS TERHADAP PENDIRIAN PERSEROAN TERBATAS OLEH USAHA MIKRO, KECIL, DAN MENENGAH ${ }^{*}$
}

\author{
Oleh \\ I Made Angga Kretanjala** \\ A. A. Ketut Sukranatha*** \\ Hukum Keperdataan Fakultas Hukum Universitas Udayana
}

\begin{abstract}
ABSTRAK
Usaha Mikro, Kecil dan Menengah merupakan usaha ekonomi produktif yang dapat membantu meningkatkan kesejahteraan rakyat, seiring perkembangan ekonomi yang pesat pemerintah mengeluarkan kebijakan perubahan modal dasar pendirian Perseroan terbatas dengan tujuan mempermudah pendirian Perseroan yang nantinya dapat membantu pertumbuhan Usaha Mikro, Kecil dan Menengah. Permasalahan dalam penulisan ini adalah bagaimana ketentuan modal dasar Perseroan Terbatas dengan berlakunya Peratauran Pemerintah Nomor 29 Tahun 2016 dan dengan berlakunya Peraturan Pemerintah Nomor 29 Tahun 2016 bagaimanakah akibat hukumnya terhadap Usaha Mikro, Kecil dan Menengah yang ingin mendirikan Perseroan Terbatas. Jenis penelitian yang digunakan dalam penelitian ini adalah penelitian hukum normatif dengan bahan hukum primer berupa ketentuan hukum dan perundang-undangan, serta ditunjang dengan bahan hukum sekunder dan tersier terkait dengan permasalahan yang dibahas dan dikumpulkan dengan studi kepustakaan. Pendekatan yang digunakan dalam penelitian ini adalah pendekatan perundang-undangan dan pendekatan analisis konsep hukum. Ketentuan modal dasar pada Peraturan Pemerintah Nomor 29 Tahun 2016 Tentang Perubahan Modal Dasar Perseroan Terbatas bertentangan dengan ketentuan Undang-Undang Nomor 40 Tahun 2007 Tentang Perseroan terbatas sehingga berdasarkan asas lex superior derogat legi inferior ketentuan pada peraturan pemerintah tidak dapat mengenyampingkan ketentuan dari Undang-Undang kemudian

* Makalah ilmiah yang berjudul akibat hukum dari peraturan perubahan modal dasar perseroan terbatas terkait pendirian perseroan terbatas oleh usaha mikro, kecil, dan menengah, merupakan ringkasan skripsi dengan mahasiswa sebagai penulis pertama dan pembimbing skripsi sebagai penulis kedua.

${ }^{* *}$ Penulis Pertama : I Made Angga Kretanjala adalah mahasiswa Fakultas Hukum Universitas Udayana. Korespondensi: anggakertajala1@gmail.com.

${ }_{* * *}$ Penulis Kedua : A. A. Keut Sukranatha, SH., MH adalah dosen Fakultas Hukum Universitas Udayana.
\end{abstract}


bagi Usaha Mikro yang hendak mendirikan Perseroan Terbatas harus mengikuti ketentuan pada Undang-Undang Nomor 40 Tahun 2007 Tentang Perseroan Terbatas.

\title{
Kata Kunci : Modal Dasar, Perseroan Terbatas, Usaha Mikro, Kecil, dan Menengah
}

\begin{abstract}
Micro, Small and Medium Enterprises are productive economic enterprises that can help improve people's welfare, along with rapid economic development the government issued a policy to change the authorized capital of the establishment of the Company in order to facilitate the establishment of the Company which would later help the growth of Micro, Small and Medium Enterprises. The problem in this paper is how the provisions of the Limited Liability Company capital with the enactment of Government Regulation Number 29 of 2016 and with the enactment of Government Regulation Number 29 of 2016 what are the legal consequences for Micro, Small and Medium Enterprises that want to establish a Limited Liability Company. The type of research used in this study is normative legal research with primary legal materials in the form of legal and regulatory provisions, and supported by secondary and tertiary law materials related to the issues discussed and collected by literature study. The approach used in this research is the legal approach and the legal concept analysis approach. Provisions on authorized capital in Government Regulation Number 29 of 2016 concerning Amendments to Limited Liability Companies are contrary to the provisions of Law Number 40 of 2007 concerning Limited Liability Companies so based on the principle of superior lex derogat legi inferior provisions in government regulations cannot exclude provisions of the Act later for Micro Enterprises wishing to establish a Limited Liability Company must follow the provisions of Law Number 40 of 2007 concerning Limited Liability Companies.
\end{abstract}

\section{Keywords : Authorized Capital, Limited Liability Company, Micro, Small, and Medum Enterprises}

\section{PENDAHULUAN}

\section{$1.1 \quad$ Latar Belakang Masalah}

Perusahaan di Negara Indonesia dapat di golongkan menjadi 2 (dua) macam yakni Perusahaan berbentuk Badan Hukum dan Perusahaan yang bukan badan hukum. Perusahaan yang 
berbetuk Badan Hukum pertanggung jawabannya hanya sebatas pada harta pengurus saja, sedangkan perusahaan yang bukan berbadan hukum memiliki tanggung jawab penuh. Suatu badan dapat dikatakan sebagai badan hukum apabila telah memenuhi syarat-syarat tertentu diantaranya adalah memiliki harta kekayaan yang tidak bercampur atau terpisah, memiliki kepentingan dan memiliki beberapa pengurus. ${ }^{1}$ Ketiga syarat ini merupakan syarat materiil suatu badan hukum, terpenuhinya syarat-syarat meteriil di atas belum menutup kemungkinan tidak menjadikan suatu lembaga menjadi badan hukum, lembaga yang ingin menjadikan dirinya sebagai badan hukum juga harus memenuhi beberapa persyaratan formal badan hukum, syarat formal badan hukum ini adalah adanya pengakuan dari Negara atau Undang-Undang yang menyatakan bahwa lembaga tersebut memang benar merupakan suatu badan hukum, barulah dapat dikatakan bahawa benar suatu perusahaan yang telah memenuhi syarat-syarat tersebut dapat dikatakan sebagai badan hukum. ${ }^{2}$

Pemerintah memberlakukan peraturan pemerintah Nomor 29 Tahun 2016 Tentang Perubahan Modal Dasar Perseroan Terbatas yang bertujuan untuk mempermudah pendirian Perseroan Terbatas dengan mengutamakan Asas Kebebasan Berkontrak, harapannya dengan diberlakukannya Peraturan Pemerintah Nomor 29 Tahun 2016 tentang Perubahan Modal Dasar Perseroan Terbatas ini dapat membantu mengembangkan dan memajukan Usaha Mikro, Kecil dan menengah. Sebelum Peraturan Pemerintah Nomor 29 Tahun 2016 Tentang Perubahan

\footnotetext{
${ }^{1}$ Ridwan Kharirandy et, al, 2003, Pengantar Hukum Dagang Indonesia, Jilid II, Gama Media, Yogyakarta, h. 23.

${ }^{2}$ Ida Ayu Sukihana, dan I Gede Agus Kurniawan, Pelaksanaan Pasal 74 Undang Undang No. 40 Tahun 2007 Tentang Perseroan Terbatas Berkaitan Dengan Tanggung Jawab Sosial Perusahaan Di Kabupaten Tabanan, Vol. 39, No.3 : 193-204 Juni 2018, Jurnal Kertha Patrika Universitas Udayana, Bali.
} 
Modal Dasar Perseroan Terbatas ini diberlakukan Pengaturan mengenai ketentuan Modal Dasar Perseroan Terbatas sendiri diatur pada Undang-Undang Nomor 40 Tahun 2007 Tentang Perseroan Terbas. Pelaksanaan kontrak sebagaimana ditentukan dalam Pasal 1338 Ayat (2) KUH Perdata. Dalam kaitannya dengan pelaksanaannya etikad baik (bona fides) diartikan prilaku yang patut dan layak antara kedua belah pihak. Kedua itikad baik juga diartikan sebagai keadaan tidak mengetahui adanya cacad, seperti misalnya pembayaran dengan etikad baik sebagaimana diatur dalam Pasal 1386 KUH Perdata. ${ }^{3}$ Berdasarkan tujuan dari Berlakunya Peraturan Pemerintah yang hendak memajukan Usaha Mikro, Kecil dan Menengah dengan memberlakukan Peraturan Pemerintah yang pada intinya memberikan kebebasan kepada para pihak pendiri Perseroan Terbatas untuk menentukan modal dasar pendirian Perseroan Terbatas sesuai dengan kesepakatan para pihak, hal ini tidak sesuai dengan ketentuan yang mengatur prihal modal dasar Perseroan Terbatas yang diatur pada UndangUndang Nomor 40 Tahun 2007 Tentang Perseroan Terbatas dimana pada Pasal 32 Undang-Undang Nomor 40 Tahun 2007 Tentang Perseroan Terbatas menentukan besaran modal dasar Perseroan Terbatas adalah paling sedikit Rp.50.000.000,- (lima puluh juta rupiah).

Berlakunya Peraturan Pemerintah Nomor 29 Tahun 2016 Tentang Perubahan Modal Dasar Perseroan Terbatas memberikan peluang kemudahan kepada pelaku usaha pemula yang ingin mendirikan suatu badan usaha Perseroan Terbatas dengancara memberikan kebebasan untuk menentukan modal dasar pendirian Perseroan Terbatas yang akan didirikan dengan harapan mampu

3 I Made Sarjana, Desak Putu Dewi Kasih, dan I Gusti Ayu Kartika, Menguji Asas Droit De Suite dalam Jaminan Fidusia, Vol. IV, No.3 : 425-441 September 2015, Jurnal Magister Hukum Universitas Udayana, Bali. 
memberikan kesempatan kepada Usaha Mikro, Kecil dan Menengah untuk turut serta membantu pertumbuhan ekonomi nasional. Usaha Mikro, Kecil dan Menengah merupakan usaha yang mampu memperluas lapangan kerja, memberikan pelayanan ekonomi secara luas kepada masyarakat dan dapat berperan dalam proses pemerataan dan peningkatan pendapatan masyarakat serta berperan mewujudkan stabilitas perekonomian nasional. Usaha Mikro, Kecil dan Menengah diatur pada UndangUndang Nomor 20 Tahun 2008 Tentang Usaha Mikro, Kecil dan Menengah.

\subsection{Tujuan Penulisan}

Penulisan ini bertujuan untuk mengetahui ketentuan modal dasar Perseroan Terbatas dengan berlakunya Peraturan Pemerintah Nomor 29 Tahun 2016 Tentang Perubahan Modal Dasar Perseroan Terbatas dan untuk memahami akibat hukum dari berlakunya Peraturan Pemerintah Nomor 29 Tahun 2016 Tentang Perubahan Modal Dasar Perseroan Terbatas terhadap Usaha Mikro, Kecil dan Menengah yang ingin mendirikan Perseroan Terbatas.

\section{ISI MAKALAH}

\subsection{Metode Penelitian}

Metode peneltian yang digunakan adalah metode penelitian hukum normatif dengan bahan hukum primer berupa ketentuan hukum dan perundang-undangan, serta ditunjang dengan bahan hukum sekunder dan tersier terkait dengan permasalahan yang dibahas dan dikumpulkan dengan studi kepustakaan. 4

4 Soerjono Soekanto dan Sri Mamuji, 2008, Penelitian Hukum Normatif Suatu Tinjauan Singkat, PT. Raja Grafindo Persada, Jakarta, h. 1. 


\subsection{Hasil dan Pembahasan}

\subsubsection{Pendirian Perseroan Terbatas Oleh Usaha Mikro, Kecil dan Menengah Dengan Berlakunya Peraturan Pemerintah Nomor 29 Tahun 2016 Tentang Perubahan Modal Dasar Perseroan Terbatas}

Usaha Mikro, Kecil dan Menengah merupakan Usaha ekonomi produktif milik orang perorangan dan/atau badan Usaha yang bukan merupakan anak perusahaan atau cabang perusahaan yang dimiliki, dikuasai, langsung maupun tidak langsung dari usaha besar yang memenuhi kriteria dari masingmasing Usaha Mikro, Usaha Kecil dan Usaha Menengah yang diatur pada ketentuan Undang-Undang Nomor 20 Tahun 2008 Tentang Usaha Mikro, Kecil, dan Menengah. ${ }^{5}$ Kriteria dari masingmasing Usaha Mikro, Kecil dan Menengah diatur pada ketentuan Pasal 6 Undang-Undang Nomor 20 Tahun 2008 Tentang Usaha Mikro Kecil dan Menengah yang menentukan bahwan Usaha mikro memiliki kekayaan bersersih kurang dari Rp.50.000.000,(lima puluh juta rupiah) dan memiliki hasil penjualan tahunan paling banyak Rp.300.000.000 (tiga ratus juta rupiah).

Usaha Kecil memiliki kekayaan bersih lebih dari Rp.50.000.000,- (lima puluh juta rupiah) hingga palingbanyak Rp.500.000.000,- (lima ratus juta rupiah) dan memiliki hasil penjualan tahunan lebih dari Rp.300.000.000,- (tiga ratus juta rupiah) sapai dengan peling banyak Rp.2.500.000.000,- (dia milyar lima ratus juta rupiah).

Kriteria dari Usaha Menengah memiliki kekayaan bersih lebih dari Rp.500.000.000,- (lima ratus juta rupiah) hingga Rp.10.000.000.000,- (sepuluh milyar rupiah) dan memiliki hasil

5 Tulus T.H. Tambunan, 2017, Usaha Mukro, Kecil dan Menengah, Ghalia Indonesia, Bogor, h. 1. 
penjualan tahunan lebih dari Rp.2.500.000.000,- (dua milyar lima ratus juta rupiah) sampai dengan paling banyak Rp.50.000.000.000,- (lima puluh milyar rupiah). ${ }^{6}$

Berdasarkan kriteria dari masing-masing Usah Mikro, Usaha Kecil dan Usaha Menengah bila dikaitkan dengan ketentuan modal dasar pendirian Perseroan Terbatas yang pada ketentuan Pasal 32 Undang-Undang Nomor 40 Tahun 2007 Tentang Perseroan Terbatas yang menentukan Modal Dasar Perseroan Terbatas paling sedikit Rp.50.000.000,- (lima puluh juta rupiah) maka Usaha Kecil dan Usaha Besar dapat mendirikan Perseroan Terbatas sesuai dengan prosedur dan mekanisme pendirian Perseroan Terbatas namun Usaha Mikro tidak dapat memenuhi persyaratan pendirian Perseroan Terbatas maka dari itu Pemerintah Nergara Republik Indonesia memberlakukan Peraturan Pemerintah Nomor 29 Tahun 2016 Tentang Perubahan Modal Dasar Perseroan Terbatas. Peraturan Pemerintah Nomor 29 Tahun 2016 Tentang Perubahan Modal Dasar Perseroan Terbatas di berlakukan untuk mempermudah pendirian badan usaha yang berbadan hukum yakni Perseroan Terbatas.

Untuk menjamin iklim penanaman modal yang kondusif, pemerintah telah mengesahkan Undang-Undang Nomor 40 Tahun 2007 Tentang Perseroan Terbatas yang mulai berlaku pada tanggal 16 Agustus 2007, namun dalam pelaksanaannya terdapat substansi yang cukup sulit untuk dilaksanakan dan menyulitkan dunia usaha, khususnya bagi pengusaha pemula. Oleh karena itu, perlu dilakukan penyesuaian peraturan dengan perkembangan kebutuhan masyarakat. Penyesuaian tersebut dimaksudkan untuk memberikan kemudahan berusaha, dan lebih menjamin ketertiban dunia usaha dalam investasi dengan mengubah

\footnotetext{
${ }^{6}$ Mulhadi, 2016, Hukum Perusahaan Bentuk-bentuk Badan Usaha di Indonesia, Raja Grafindo Persada, Jakarta, h.32.
} 
besaran modal dasar yang dirasakan masih memberatkan bagi para pengusaha pemula. Ketentuan kemudahan berusaha tersebut berupa perubahan terhadap modal dasar Perseroan Terbatas yang semula ditentukan paling sedikit Rp 50.000.000,(lima puluh juta rupiah) menjadi diserahkan sepenuhnya pada kesepakatan para pendiri Perseroan Terbatas. Penyerahan penentuan besaran modal dasar Perseroan Terbatas kepada para pendiri Perseroan Terbatas dimaksudkan sebagai upaya Pemerintah untuk menghormati asas kebebasan berkontrak yang memberikan kebebasan seluas-luasnya kepada masyarakat untuk mengadakan perjanjian dalam mendirikan Perseroan Terbatas berdasarkan ketentuan dalam Hukum perdata.

Ketentuan dari Peraturan Pemerintah Nomor 29 Tahun 2016 Tentang Perubahan Modal Dasar Perseroan Terbatas jelas bertentangan dengan ketentuan Pada Pasal 32 Undang-Undang Nomor 40 Tahun 2007 Tentang Perseroan Terbatas yang pada Pasal 32 dengan jelas menentukan nilai nominal dari modal dasar Perseroan Terbatas paling sedikit Rp.50.000.000,- (lima puluh juta rupiah). Bila dikaitkan dengan hierarki Peraturan Perundangundangan maka ketentuan dari Peraturan Pemerintah Nomor 29 Tahun 2016 Tentang Perubahan Modal Dasar Perseroan Terbatas tidak dapat mengenyampingkan ketentuan yang masih berlaku yakni ketentuan dari Undang-Undang Nomor 40 Tahun 2007 Tentang Perseroan Terbatas hal ini diperkuat dengan Asas Lex Superior Derogat Legi Inferior.

Peraturan Pemerintah Nomor 29 Tahun 2016 Tentang Perubahan Modal Dasar Perseroan Terbatas tidak dapat mengenyampingkan ketentuan Undang-Undang Nomor 40 Tahun 2007 Tentang Perseroan Terbatas maka dari itu, Usaha Mikro, Kecil dan Menengah dalam mendirikan Perseroan Terbatas tetap 
berpedoman pada ketentuan Undang-Undang Nomor 40 Tahun 2007 Tentang Perseroan Terbatas.

\subsubsection{Keabsahan Modal Dasar Pendirian Perseroan Terbatas Dengan Berlakunya Peraturan Pemerintah Nomor 29 Tahun 2016 Tentang Perubahan Modal Dasar Perseroan Terbatas}

Modal merupakan salah satu unsur penting dalam pendirian suatu badan usaha, hal ini terutama dihubungkan dengan arah kebijakan dalam kegiatan awal berdirinya badan usaha tersebut hingga kegiatan yang dilakukan selanjutnya dalam usaha-usaha untuk mengembangkan usaha. Dalam pendirian suatu badan usaha diperlukan suatu perhitungan yang baik mengenai modal dasar dengan mempertimbangkan seberapa besar badan usaha itu mampu memenuhi kebutuhan dana yang akan digunakan untuk beroperasi dan mengembangkan usahanya.

Pengaturan modal dasar yang baik dari pendirian suatu badan usaha mempunyai ciri-ciri sebagai berikut :

a. Memiliki struktur komposisi yang jelas,

b. Memberikan batasan jumlah equity yang tepat,

c. Mampu mengantisipasi pengaturan isu-isu yang terkait,

d. Dalam hal badan usaha tidak mampu menjaga jumlah modal dasar dengan baik maka badan usaha dapat memiliki pilihan atas metode yang dirasa terbaik bagi badan usaha memenuhi modal yang cukup terkait dengan keadaan finansial, kepentingan anggota, serta hal-hal lain yang menjadi pertimbangan bagi badan usaha tersebut. 7

Berdasarkan Undang-Undang Nomor 40 Tahun 2007 Tentang Perseroan Terbatas mengatur ketentuan tentang modal dasar pada ketentuan Pasal 32 yang menetapkan bahwa modal

7 Olga Petroseviciene, 2009, The Nature of Authotorized Capital and Some Rules of Cpital Maintenance, Lithuania, Mykolas Rumeris University, h. 9. 
dasar Perseroan Terbatas paling sedikit Rp.50.000.000,- (lima puluh juta rupiah), kemudian setidaknya 25\% (dua puluh lima persen) dari modal dasar sekitar Rp. 12.500.000,- harus di tempatkan dan disetor penuh, penempatan dan penyetoran modal ini dibuktikan dengan bukti pembayaran yang sah. ${ }^{8}$

Ketentuan mengenai Modal Dasar pada Pasal 32 UndangUndang Nomor 40 Tahun 2007 Tentang Perseroan Terbatas diatur dengan jelas bahwa modal dasar dari Perseroan Terbatas adalah paling sedikit Rp.50.000.000,- (lima puluh juta rupiah) dan setidaknya 25\% (dua puluh lima persen) dari modal dasar harus ditempatkan dan disetor penuh.

Seiring perkembangan perekonomian nasional Pemerintah Negara Republik Indonesia memberlakukan Peraturan Pemerintah Nomor 29 Tahun 2016 Tentang Perubahan Modal Dasar Perseroan Terbatas dengan tujuan mempermudah pendirian Perseroan Terbatas tepatnya pada modal dasar dari perseroan terbatas yang pada ketentuan pada Pasal 32 Undang-Undang Nomor 40 Tahun 2007 Tentang Perseroan Terbatas dikira sudah tidak sesuai dengan perkembangan eknomi dan dengan mengedepankan asas kebebasan berkontrak yang nantinya dapat membantu perkembangan dan kemajuan dari Usaha Mikro, Kecil dan Menengah.

Ketentuan dari Pasal 1 ayat (3) Peraturan Pemerintah Nomor 29 Tahun 2016 Tentang Perubahan Modal Dasar Perseroan Terbatas menentukan bahwa prihal bersaran modal dasar pendirian Perseroan Terbatas diserahkan sepenuhnya kepada para pihak pendiri Perseroan Terbatas, maksud dari pengaturan ini adalah ketentuan akan besaran modal dasar pendirian Perseroan Terbatas sepenuhnya diberikan kepada kesepakatan para pendiri

8 Zaenal Asyhadie, 2005, Hukum Bisnis dan Pelaksanaannya di Indonesia, Edisi Revisi, Rajawali Pers, Jakarta, h.34. 
Perseroan Terbatas dimana para pihak pendiri bebas menentukan besaran modal dasar pendirian Perseroan Terbatas.

Mengenai modal ditempatkan dan disetor penuh paling sedikit 25\% (dua puluh lima persen) dari modal dasar harus di tempatkan dan disetor penuh yang dibuktikan dengan bukti penyetoran yang sah, merujuk pada ketentuan Pasal 1 ayat (3) Peraturan Pemerintah Nomor 29 Tahun 2016 Tentang Perubahan Modal Dasar Perseroan Terbatas ketentuan Pasal 2 ini menentukan 25\% dari Modal dasar harus di tempatkan dan disetor penuh dengan penyertaan bukti pembayaran yang sah.

Ketentuan dari Peraturan Pemerintah Nomor 29 Tahun 2016 Tentang Perubahan Modal Dasar Perseroan Terbatas ini jelas bertentangan dengan Ketentuan modal dasar pada UndangUndang Nomor 40 Tahun 2007 Tentang Perseroan Terbatas dimana pada ketentuan Pasal 1 Peraturan Pemerintah Nomor 29 Tahun 2016 Tentang Perubahan Modal Dasar Perseroan Terbatas tidak menentukan berapa nominal modal dasar pendirian Perseroan Terbatas sedangkan pada ketentuan Pasal 32 UndangUndang Nomor 40 Tahun 2007 Tentang Perseroan Terbatas menegaskan dengan jelas modal dasar Perseroan Terbatas sebesar Rp. 50.000.000,- (limapuluh juta rupiah).

Ketentuan dari Peraturan Pemerintah Nomor 29 Tahun 2016 Tentang Perubahan Modal Dasar Perseroan Terbatas yang bertentangan dengan ketentuan Undang-Undang Nomor 40 Tahun 2007 Tentang Perseroan Terbatas adalah ketentuan tentang Modal Dasar dimana Pada Ketentuan Pasal 32 Undang-Undang Nomor 40 Tahun 2007 Tentang Perseroan Terbatas menetapkan bahwa modal dasar perseroan Terbatas adalah paling sedikit Rp.50.000.000,- (lima puluh juta rupiah), sedangkan pada ketentuan Pasal 1 ayat (3) Peraturan Pemerintah Nomor 29 Tahun 
2016 Tentang Perubahan Modal Dasar Perseroan Terbatas menentukan bahwa para pihak pendiri Perseroan Terbatas dapat menentukan besaran modal dasar pendirian Perseroan Terbatas.

Ketentuan akan modal dasar Perseroan Terbatas dengan berlakunya Peraturan Pemerintah Nomor 29 Tahun 2016 Tentang Perubahan Modal Dasar Perseroan Terbatas tidak dapat mengesampingkan atau tidak dapat menggantikan ketentuan modal dasar yang masih diatur pada ketentuan Pasal 32 UndangUndang Nomor 40 Tahun 2007 Tentang Perseroan Terbatas, bila ditinjau dari Asas Lex Superior Derogat Legi Inferiori yang menjelaskan bahwa Undang-Undang yang lebih tinggi melumpuhkan peraturan perundang-undangan yang lebih rendah. 9

Berdasarkan hierarki Peraturan Perundang-undangan dan diperkuat dengan Asas Lex Superior Derogat Legi Inferiori maka ketentuan modal dasar Perseroan Terbatas dengan berlakunya Peraturan Pemerintah Nomor 29 Tahun 2016 Tentang Perubahan Modal Dasar Perseroan Terbatas tidak dapat menggantikan atau mengenyampingkan ketentuan dari modal dasar Perseroan Terbatas yang diatur pada Pasal 32 Undang-Undang Nomor 40 Tahun 2007 Tentang Perseroan Terbatas, berdasarkan hal tersebut maka ketentuan dari Undang-Undang Nomor 40 Tahun 2007 Tentang Perseroan Terbatas masih tetap berlaku dan menjadi pedoman dalam mendirikan, menjalankan hingga pembubaran Perseroan Terbatas.

\section{PENUTUP}

\subsection{Kesimpulan}

9 Sudikno Mertokusumo, 2002, Mengenal Hukum (Suatu Pengantar), Liberty, Yogyakarta, h. 85. 
1. Peraturan Pemerintah Nomor 29 Tahun 2016 Tentang Perubahan Modal Dasar tidak dapat mengenyampingkan ketentuan dari ketentuan Undang-Undang Nomor 40 Tahun 2007 Tentang Perseroan Terbatas oleh karena itu Usaha Mikro tidak dapat mendirikan Perseroan Terbatas karena dilihat dari kriteria Usaha Mikro yang memiliki kekayaan bersih kurang dari Rp.50.000.000,-(lima puluh juta rupiah) maka Usaha Mikro tidak dapat memenuhi syarat pendirian Perseroan Terbatas yang diatur pada ketentuan Undang-Undang Nomor 40 Tahun 2007 Tentang Perseroan Terbatas.

2. Berdasarkan hierarki Peraturan Perundang-Undangan dan diperkuat dengan asas Lex Superior Derogat Legi Inferior maka Peraturan Pemerintah Nomor 29 Tahun 2016 Tentang Perubahan Modal Dasar Perseroan Terbatas tidak dapat mengesampingkan ketentuan modal dasar yang diatur pada Undang-Undang Nomor 40 Tahun 2007 Tentang Perseroan terbatas yang pada Pasal 32 menentukan modal dasar Perseroan Terbatas paling sedikit Rp.50.000.000,- (lima puluh juta rupiah) maka ketentuan dari Undang-Undang Nomor 40 Tahun 2007 Tentang Perseroan Terbatas yang berlaku.

\subsection{Saran}

1. Ketentuan perubahan modal dasar Perseroan Terbatas yang merupakan kebijakan Pemerintah yang diatur pada Peraturan Pemerintah Nomor 29 Tahun 2016 Tentang Perubahan Modal Dasar Perseroan Terbatas hendaknya ditinjau kembali karena ketentuan dari Peraturan Pemerintah mengenai perubahan modal dasar ini tidak 
sesuai dengan ketentuan pada Undang-Undang Nomor 40

Tahun 2007 Tentang Perseroan Terbatas.

2. Sosialisasi dari pemberlakuan kebijakan pemerintah dalam memberlakukan Peraturan Pemerintah Nomor 29 Tahun 2016 Tentang Perubahan Modal Dasar Perseroan Terbatas hendaknya dilaksanakan terlebih dahulu sehingga pelaku usaha dapat memanfaatkan kebijakan ini dengan sempurna dan pelaku usaha juga dapat memilih badan usaha apa yang hendak didirikannya sesuai dengan kemampuan yang dimilikinya

\section{DAFTAR PUSTAKA}

\section{Buku-Buku}

Mulhadi, 2016, Hukum Perushaan Bentuk-Bentuk Bdan Usaha di Indonesia, Raja Grafido Prasada, Jakarta

Olga Petroseviciene, 2009, The Nature of Authotorized Capital and Some Rules of Cpital Maintenance, Lithuania, Mykolas Rumeris University.

Ridwan Kharirandy et, al, 2003, Pengantar Hukum Dagang Indonesia, Jilid II, Gama Media, Yogyakarta.

Soerjono Soekanto dan Sri Mamuji, 2008, Penelitian Hukum Normatif Suatu Tinjauan Singkat, PT. Raja Grafindo Persada, Jakarta.

Sudikno Mertokusumo, 2002, Mengenal Hukum (Suatu Pengantar), Liberty, Yogyakarta.

Tulus T.H. Tambunan, 2017, Usaha Mukro, Kecil dan Menengah, Ghalia Indonesia, Bogor.

Zaenal Asyhadie, 2005, Hukum Bisnis dan PElaksanaannya di Indonesia, Rajawali Pers, Jakarta..

\section{Jurnal}

I Made Sarjana, Desak Putu Dewi Kasih, dan I Gusti Ayu Kartika, Menguji Asas Droit De Suite dalam Jaminan Fidusia, Vol. IV, No.3 : 425-441 September 2015, Jurnal Magister Hukum Universitas Udayana, Bali. 
Ida Ayu Sukihana, dan I Gede Agus Kurniawan, Pelaksanaan Pasal 74 Undang Undang No. 40 Tahun 2007 Tentang Perseroan Terbatas Berkaitan Dengan Tanggung Jawab Sosial Perusahaan Di Kabupaten Tabanan, Vol. 39, No.3 : 193-204 Juni 2018, Jurnal Kertha Patrika Universitas Udayana, Bali.

\section{Peraturan Perundang-Undangan}

Kitab Undang-Undang Hukum Perdata, Burgerlijk Wetboek, 2004, Diterjemahan R. Subekti dan R. Tjitrosudibyo, Pradnya Paramita, Bandung.

Republik Indonesia, Undang-Undang Nomor 40 Tahun 2007 Tentang Perseroan Terbatas, Lembaran Negara Republik Indonesia Tahun 2007 Nomor 106 Tambahan Lembaran Negara Republik Indonesia Nomor 4756.

Republik Indonesia, Undang-Undang Nomor 20 Tahun 2008 Tentang Usaha Mikro, Kecil, dan Menengah, Lembaran Negara Republik Indonesia Tahun 2008 Nomor 93 Tambahan Lembaran Negara Republik Indonesia Nomor 4866.

Peraturan Pemerintah Republik Indonesia Nomor 29 Tahun 2016 Tentang Perubahan Modal Dasar Perseroan Terbatas, Lembaran Negara Republik Indonesia Tahun 2016 Nomor 137 Tambahan Lembaran Negara Republik Indonesia Nomor 5901. 